\title{
1. Introduction to The International Rule of Law
}

\section{THE TOPIC OF THE BOOK}

This book offers a theoretical examination of the international rule of law ('IROL'). It analyses the moral and legal principle' of the rule of law ('ROL') within the international legal order, focusing on its scope, subjects and requirements. This book was motivated by the neglect of conceptual and normative theorizing of the IROL in contemporary international legal scholarship on the IROL.

The ROL refers to legal governance. ${ }^{2}$ It occupies a special and pervasive role in today's legal and political discourse on a global scale. ${ }^{3}$ The ROL is generally considered to be one of the main principles of current political morality against which social and political orders, and more specifically orders of law, ${ }^{4}$ can be evaluated..$^{5}$ It is frequently understood to be the law's 'distinctive virtue' (also referred to as the principle of legality ${ }^{6}$ ) and a condition for a decent or worthwhile legal order. ' The rule of law' must, in principle, be distinguished from 'a rule of law', which is a statement of what the law prescribes on some particular matter, ${ }^{8}$ like the rule in certain states stipulating that vehicles must

1 The ROL is also often called an ideal. For the reasons explained in ch 2, s 2, this book generally terms it a principle.

2 Grant Lamond, 'The Rule of Law' in Andrei Marmor (ed), The Routledge Companion to Philosophy of Law (Routledge 2012) 499.

3 Brian Tamanaha, On the Rule of Law: History, Politics, Theory (CUP 2004) 1-3.

4 Joseph Raz, The Authority of Law: Essays on Law and Morality (Clarendon Press 1979) 211.

5 Jeremy Waldron, 'The Rule of Law', The Stanford Encyclopedia of Philosophy (Summer edn, 2020) <https://plato.stanford.edu/entries/rule-of-law/> accessed 15 November 2020.

6 John Gardner, Law as a Leap of Faith: Essays on Law in General (OUP 2012) 196.

7 Lamond (ch 1 n 2) 495.

8 Arthur Watts, 'The International Rule of Law' (1993) 15 German Yearbook of International Law 15, 15; Waldron, 'The Rule of Law' (ch 1 n 5). 
drive on the right-hand side of the road. ${ }^{9}$ Yet, within a given legal order, the ROL or aspects of it may be protected by positive legal norms. ${ }^{10}$ Despite its prominence in legal and political discourse, the exact content of the ROL remains contested, with different conceptions being available. ${ }^{11}$ In general, the ROL is associated with formal characteristics of the law-such as public, prospective, consistent, clear and stable legal norms by which political authority is exercised within a legal order, an independent judiciary that operates according to the principles of due process, and the availability of judicial review. Some conceptions further include substantive elements, like human rights, democracy or substantive justice. ${ }^{12}$

While it is generally assumed that domestic legal orders can and do conform to and develop the ROL, this has not generally been the case for the international legal order, at least not until recently. Generally, no one would seriously question the possibility and existence of the ROL within states. It is different for international law. Indeed, there is no world sovereign. International law is generally made, applied and enforced in a decentralized way by states, and it primarily provides for rights and obligations of states. It is commonly adjudicated by a plurality of decentralized, non-hierarchically organized international courts, which generally possess special and voluntary jurisdiction. Yet, there is international law and there are international institutions. Recently, the existence of international law and institutions has led some scholars to ask whether international law can and should conform to and develop the ROL principle; and, if so, how? ${ }^{13}$ 741.01).

9 See, eg, Article 34(1) of the Swiss Road Traffic Act of 19 December 1958 (SR

${ }_{10}$ See, in particular, ch 3, s 4.3 and ch 4.

11 See, eg, Margaret Radin, 'Reconsidering the Rule of Law' (1989) 69 Boston University Law Review 781.

12 On the whole issue, Lamond (ch 1 n 2) 495; Waldron, 'The Rule of Law' (ch 1 n 5); ch 2, s 4.

13 See Jeremy Waldron, 'Are Sovereigns Entitled to the Benefit of the International Rule of Law?' (2011) 22 European Journal of International Law 315, 316 and passim on the whole issue. See, eg, James Crawford, Chance, Order, Change: The Course of International Law: General Course on Public International Law (Hague Academy of International Law 2014) chs XI-XV; Peter Rijpkema, 'The Concept of a Global Rule of Law' (2013) 4 Transnational Legal Theory 167; Stéphane Beaulac, 'The Rule of Law in International Law Today' in Gianluigi Palombella and Neil Walker (eds), Relocating the Rule of Law (Hart Publishing 2009). 
A fast-growing body of legal literature addressing the IROL is now available. ${ }^{14}$ Various academic conferences, ${ }^{15}$ research projects ${ }^{16}$ and even a journal ${ }^{17}$ have been dedicated to the topic. However, despite the proliferating interest in and works on the IROL, theoretical questions pertaining to the possibility and desirability of the IROL remain underexplored. On the one hand, most scholarly contributions to the IROL are contributions to legal doctrine, rather than to legal theory. ${ }^{18}$ They focus on the IROL at the level of positive law through, for

14 For contributions in international relations, see, eg, James Ranney, World Peace through Law: Replacing War with the Global Rule of Law (Routledge 2018); Monika Heupel and Theresa Reinold (eds), The Rule of Law in Global Governance (Palgrave Macmillan 2016); Friedrich Kratochwil, The Status of Law in World Society: Meditations on the Role and Rule of Law (CUP 2014); Bernhard Zangl, 'Is There an Emerging International Rule of Law?' (2005) 13 European Review 73.

15 For instance, the theme of the 2019 edition of the European Society of International Law's Research Forum, held on 4-5 April 2019 in Goettingen, was 'The International Rule of Law and Domestic Dimensions: Synergies and Challenges'.

16 See, eg, the research project in international law and political science 'The International Rule of Law: Rise or Decline?' on the role of international law in a changing global order, chaired by Heike Krieger and Georg Nolte, led at the Freie Universität Berlin, Humboldt-Universität zu Berlin and Universität Potsdam, resulting in, eg, Heike Krieger, Georg Nolte and Andreas Zimmermann (eds), The International Rule of Law: Rise or Decline? (OUP 2019); the research project in social sciences and law 'The Internationalization of the Rule of Law: Changing Contexts and New Challenges' on the consequences of internationalization for contemporary ROL promotion, led by André Nollkaemper, Randall Peerenboom and Michael Zürn, supported by The Hague Institute for Innovation of Law, Social Science Research Center Berlin, University of Amsterdam and La Trobe University, resulting in, eg, Machiko Kanetake and André Nollkaemper (eds), The Rule of Law at the National and International Levels: Contestations and Deference (Hart Publishing 2016); Michael Zürn, André Nollkaemper and Randall Peerenboom (eds), Rule of Law Dynamics: In an Era of International and Transnational Governance (CUP 2012); and the research project in international relations, politics and law on the ethical and institutional supports for the IROL and the matter of access to international justice, led by Simon Chesterman, Vesselin Popovski, Charles Sampford and Ramesh Thakur, supported by the Australian Research Council, Center for International Governance Innovation, UN Rule of Law Unit and United Nations University, resulting in, eg, Patrick Keyzer, Vesselin Popovski and Charles Sampford (eds), Access to International Justice (Routledge 2015); Charles Sampford and Ramesh Thakur (eds), Institutional Supports for the International Rule of Law (Routledge 2015); Vesselin Popovski (ed), International Rule of Law and Professional Ethics (Ashgate 2014).

17 See the Hague Journal on the Rule of Law, founded in 2009, which also concerns the ROL in the domestic context; Julio Faundez and others, 'Editorial: Introduction-A New Journal!' (2009) 1 Hague Journal on the Rule of Law 1, 2.

18 Regarding the IROL more generally, see, eg, Kenneth Keith, 'The International Rule of Law' (2015) 28 Leiden Journal of International Law 403; Patrick Robinson, 'Affirming the International Rule of Law' (2012) 17 European Human Rights Law 
instance, the systematization and analysis of case law. In this context, the IROL concept and its value or justification are often presumed or stipulated. At times, the IROL and international law are even used as synonyms. On the other hand, most scholarly contributions on the IROL that are contributions to legal theory, or to legal doctrine but with stronger theoretical underpinnings - and which thus deal with and question the IROL conceptually and/or normatively-tend to do so either within a specific context (eg, an international organization, such as the United Nations ('UN'), or a particular regime, such as international trade law $)^{19}$ or with a focus on one or more particular questions raised by the IROL

Review 32; Philippe Sands and Blinne Ní Ghrálaigh, 'Towards an International Rule of Law?' in Mads Andenas and Duncan Fairgrieve (eds), Tom Bingham and the Transformation of the Law. A Liber Amicorum (OUP 2009); Ian Brownlie, 'International Law at the Fiftieth Anniversary of the United Nations: General Course on Public International Law' (1995) 255 Collected Courses 1; Jacques-Yvan Morin, 'L'Etat de droit: émergence d'un principe du droit international' (1995) 254 Collected Courses 9. Regarding the IROL in a given context, see, eg, Gabrielle Marceau, A History of Law and Lawyers in the GATT/WTO: The Development of the Rule of Law in the Multilateral Trading System (CUP 2015); Geert de Baere and Jan Wouters (eds), The Contribution of International and Supranational Courts to the Rule of Law (Edward Elgar Publishing 2015); Geranne Lautenbach, The Concept of the Rule of Law and the European Court of Human Rights (OUP 2013); Giorgio Gaja and Jenny Grote Stoutenburg (eds), Enhancing the Rule of Law Through the International Court of Justice (Brill/Nijhoff 2012); André Nollkaemper, National Courts and the International Rule of Law (OUP 2011); John Murphy, The United States and the Rule of Law in International Affairs (CUP 2004).

${ }_{19}$ See, eg, Sherif Elgebeily, The Rule of Law in the United Nations Security Council Decision-Making Process: Turning the Focus Inwards (Routledge 2017); Theodore Konstadinides, The Rule of Law in the European Union: The Internal Dimension (Hart Publishing 2017); Clemens Feinäugle (ed), The Rule of Law and Its Application to the United Nations (Nomos/Hart Publishing 2016); Werner Schroeder (ed), Strengthening the Rule of Law in Europe: From a Common Concept to Mechanisms of Implementation (Hart Publishing 2016); Photini Pazartzis and Maria Gavouneli (eds), Reconceptualising the Rule of Law in Global Governance, Resources, Investment and Trade (Hart Publishing 2016); Imelda Deinla, The Development of the Rule of Law in ASEAN: The State and Regional Integration (CUP 2017); José Alvarez, 'International Organizations and the Rule of Law: Challenges Ahead' in Chia-Jui Cheng (ed), A New International Legal Order. In Commemoration of the Tenth Anniversary of the Xiamen Academy of International Law (Brill/Nijhoff 2016); Geert de Baere, Anna-Luise Chané and Jan Wouters, 'International Courts as Keepers of the Rule of Law: Achievements, Challenges, and Opportunities' (2016) 48 New York University Journal of International Law and Politics 715; Janne Nijman, 'Images of Grotius, or the International Rule of Law beyond Historiographical Oscillation' (2015) 17 Journal of the History of International Law 83; Miodrag Jovanović, 'Interpretation in International Law and International Rule of Law-Any Lesson for Jurisprudence?' in Miodrag Jovanović and Kenneth Himma (eds), Courts, Interpretation, the Rule of Law (Eleven International Publishing 2014); Machiko Kanetake, 'The Interfaces 
(eg, the 'transposability' of the ROL to the international plane or its 'definability'). ${ }^{20}$ Yet, contributions that assess the possibility and/or desirability of the IROL more comprehensively and regarding the international legal order as a whole are very rare and often cursory, since they generally consist of shorter pieces, such as book chapters and journal articles. ${ }^{21}$

The present book responds to the aforementioned deficits in the contemporary international legal scholarship on the IROL. It provides an in-depth investigation into whether, and if so how and to what degree, the current international legal order can and should conform to and develop the principle of the ROL. In addition, this book advocates a change in the way the IROL is theorized.

Between the National and International Rule of Law: The Case of UN Targeted Sanctions' (2012) 9 International Organizations Law Review 267.

20 See, eg, Kanetake and Nollkaemper (ch $1 \mathrm{n} \mathrm{16)}$; Robert McCorquodale, 'Defining the International Rule of Law: Defying Gravity?' (2016) 65 International and Comparative Law Quarterly 277; Sampford and Thakur (ch 1 n 16); Keyzer, Popovski and Sampford (ch 1 n 16); Popovski (ch 1 n 16); Richard Collins, 'The Rule of Law and the Quest for Constitutional Substitutes in International Law' (2014) 83 Nordic Journal of International Law 87; BS Chimni, 'Legitimating the International Rule of Law' in James Crawford and Martti Koskenniemi (eds), The Cambridge Companion to International Law (CUP 2012); Waldron, 'Are Sovereigns Entitled to the Benefit of the International Rule of Law?' (ch 1 n 13); Jutta Brunnée and Stephen Toope, Legitimacy and Legality in International Law: An Interactional Account (CUP 2010); Gianluigi Palombella, 'The Rule of Law beyond the State: Failures, Promises, and Theory' (2009) 7 International Journal of Constitutional Law 442; Olivier Corten, 'Rapport général: 1'Etat de droit en droit international: quelle valeur juridique ajoutée?' in SFDI (ed), L'Etat de droit en droit international: colloque de Bruxelles (Pedone 2009); Jacques Chevallier, 'Les aspects idéologiques de l'Etat de droit' in SFDI (ed), L'Etat de droit en droit international: colloque de Bruxelles (Pedone 2009); André Nollkaemper, 'The Internationalized Rule of Law' (2009) 1 Hague Journal on the Rule of Law 74; David Dyzenhaus, 'The Rule of (Administrative) Law in International Law' (2005) 68 Law and Contemporary Problems 127.

21 See, eg, Rodoljub Etinski and Bojan Tubić, 'International Law and the Rule of Law' (2016) LXIV Annals FLB-Belgrade Law Review 57; Crawford, Chance, Order, Change (ch 1 n 13) chs XI-XV; Monica Moyo, 'The International Rule of Law: An Analysis' (2014) 23 Minnesota Journal of International Law 79; Rijpkema (ch 1 n 13); Beaulac (ch 1 n 13); Simon Chesterman, 'An International Rule of Law?' (2008) 56 American Journal of Comparative Law 331; Hisashi Owada, 'Reconceptualization of the International Rule of Law in a Globalizing World' (2008) 51 Japanese Yearbook of International Law 3; Watts (ch $1 \mathrm{n}$ 8); Philip Allott, Towards the International Rule of Law: Essays in Integrated Constitutional Theory (Cameron May 2005). The only book I could find that seems to deal more comprehensively and from a general perspective with the issue of the possibility of the IROL is the Italian book $\dot{E}$ possibile una legalità globale? Il Rule of law e la governance del mondo (Il mulino 2012) by Gianluigi Palombella. 
In short, most scholars concede that, due to international law's specific features, a mere transposition of the domestic conception of the ROL to the international level may be inappropriate. Instead, what they advocate is the adjustment of the domestic understanding of the ROL in order to account for the specificities of international law. ${ }^{22}$ Two approaches can be distinguished. ${ }^{23}$ The conventional approach to the IROL, taken by authors such as Arthur Watts and Stéphane Beaulac, ${ }^{24}$ consists in treating states as beneficiaries of the ROL internationally in a similar way to that in which individuals are treated domestically and, hence, in applying the ROL to them analogically to the way in which it is applied to individuals in the domestic legal order. However, this entails a dichotomy in terms of the benefiting subjects of the ROL between the domestic and international levels. Moreover, the conventional approach reproduces the classical understanding of international law, which treats states as individuals domestically and international law as individual contracts domestically and which does not adequately reflect international law's current features and the role of states in its making, application and enforcement.

This has led some scholars, most notably Jeremy Waldron, ${ }^{25}$ to criticize the conventional approach to the IROL as a 'misconceived' analogy and to propose a new approach to the IROL as benefiting individuals. This new approach conceives of states as legal constructions existing for the sake of their constituents and as the officials of international law with regard to its making, application and enforcement. Accordingly, Waldron insists, states cannot benefit from the IROL in the same way that individuals are protected by the domestic rule of law ('DROL'). Rather, the ROL requirements that apply to the state internally must remain the same externally and protect individuals against the state's internal and external actions. ${ }^{26}$ The new approach to the IROL implies understanding the IROL together with, and closely related to, the DROL. The present book responds to the insufficiencies of the conventional approach by taking up its recent critique. It endorses and fleshes out the new approach to the

22 On this issue, see, in particular, ch 5, s 3.

23 A version of this can already be found in Denise Wohlwend, 'The International Rule of Law and Equality: Whose Equality?' in Samantha Besson and Andreas Ziegler (eds), Egalité et non-discrimination en droit international et européen (Schulthess/ LGDJ 2014) 111-115.

24 See Beaulac (ch 1 n 13); Watts (ch 1 n 8).

25 See Waldron, 'Are Sovereigns Entitled to the Benefit of the International Rule of Law?' (ch 1 n 13). See also Samantha Besson, 'Sovereignty, International Law and Democracy' (2011) 22 European Journal of International Law 373; Samantha Besson, 'The Authority of International Law-Lifting the State Veil' (2009) 31 Sidney Law Review 343.

26 Waldron, 'Are Sovereigns Entitled to the Benefit of the International Rule of Law?' (ch 1 n 13) 322 ff, 341. 
IROL by considering it systematically, including neglected issues, such as the application of the new approach to international organizations.

\section{THE IMPORTANCE OF THE TOPIC}

The book's topic is important for at least three reasons. First, through its theoretical approach to the IROL, the book expands the predominantly legal doctrinal literature on the IROL by providing conceptual and normative insights and explanations. By opening up space for theoretical considerations, doctrinal treatments of the IROL stand to gain in explanatory power, rigour and accuracy. Second, it is essential for attempts to conceptually and normatively theorize the IROL to reflect the features of the contemporary international legal order. By endorsing and fleshing out the new approach to the IROL, the present book engages with, critically appraises and, to some extent, revises the analyses and explicit or implicit arguments put forward by existing legal theoretical works on the IROL, thereby making a novel contribution to the field. Third, elucidating the concept of the IROL can be understood as a sub-category of the elucidation of the concepts of international law and international legality. By adopting the new approach to the IROL, the present book improves and deepens our understanding of conceptual questions of international law. This is of great significance, since '[a] complete understanding of the normative questions raised by international law [ie, regarding the standards of its legitimacy or the values it should pursue and realize] requires a clear understanding of the legality of international law ...' ${ }^{27}$

Moreover, studying the IROL, be it on the level of theory or positive law, is important, given that the ROL has become a topic of central concern to the practice of international law. In the aftermath of the Second World War, but especially after the end of the Cold War, the ROL in international law has been increasingly referred to in the work of international organizations, both at the regional and universal levels. ${ }^{28}$ Initially, international law and practice primarily concerned the ROL as an international principle directed at the legal orders of states. Gradually, international law and practice then also concerned the ROL as an international principle directed at the international legal order. The ROL thereby plays both an instrumental and non-instrumental role. Not all international organizations possess norms of positive international law

27 Samantha Besson and John Tasioulas, 'Introduction' in Samantha Besson and John Tasioulas (eds), The Philosophy of International Law (OUP 2010) 7, 2.

28 Pierre d'Argent, Olivier Corten and Pierre Klein, 'Avant-propos' in SFDI (ed), L'Etat de droit en droit international: colloque de Bruxelles (Pedone 2009) 5; Lautenbach (ch 1 n 18) 1-2; Corten (ch 1 n 20) 12-14. 
to protect the principle. ${ }^{29}$ In this vein, the DROL has been promoted and safeguarded through international law and institutions as an essential element for the realization of human rights and the furtherance of peace and security and development. ${ }^{30}$ In addition, different regional organizations, such as the European Union ('EU') or the African Union ('AU'), have committed themselves to the ROL as one of their common values, principles or objectives, ${ }^{31}$ and promoted and safeguarded it at the domestic ${ }^{32}$ and, at times, international levels. ${ }^{33}$ Importantly, in the 2005 World Summit Outcome, the UN member states recognized the ROL as one of the organization's 'universal and indivisible core values and principles', as well as 'the need for universal adherence to and implementation of the rule of law at both the national and international levels'. ${ }^{34}$ Since 2006 , '[t] he rule of law at the national and international levels' has been an agenda item for the UN General Assembly, and annual resolutions reaffirming this commitment have been adopted. ${ }^{35}$

Further, the arguably growing importance of the IROL constitutes another reason for its (theoretical or doctrinal) analysis. ${ }^{36}$ In short, in the course of the

29 On these issues, see ch 4.

30 Chesterman, 'An International Rule of Law?' (ch 1 n 21) 343-350. See, eg, the preamble of the Universal Declaration of Human Rights, UNGA Res 217 (III) A (10 December 1948) UN Doc A/RES/217(III) ('UDHR'); the preamble of the Convention for the Protection of Human Rights and Fundamental Freedoms (adopted 4 November 1950, entered into force 3 September 1953) ETS 005 ('ECHR'); the preamble of the Charter of Fundamental Rights of the European Union [2012] OJ C326/391 ('EU Fundamental Rights Charter'); Organization for Security and Co-operation in Europe ('OSCE'), 'ODIHR and the Rule of Law' Factsheet (9 July 2013) <www.osce.org/ odihr/103448> accessed 7 November 2020; The World Bank, 'Worldwide Governance Indicators' $<$ http://info.worldbank.org/governance/wgi/\# home $>$ accessed 7 November 2020.

31 Helmut Aust and Georg Nolte, 'International Law and the Rule of Law at the National Level' in Michael Zürn, André Nollkaemper and Randall Peerenboom (eds), Rule of Law Dynamics: In an Era of International and Transnational Governance (CUP 2012) 57.

32 See, eg, the preamble and Article 3 of the Statute of the Council of Europe (adopted 5 May 1949, entered into force 3 August 1949) ETS 001 ('Statute of the $\mathrm{CoE}$ '); the preamble and Articles 2 and 49 of the Consolidated Version of the Treaty on European Union [2012] OJ C326/13 ('TEU'); the preamble of the Constitutive Act of the African Union (adopted 7 November 2000, entered into force 26 May 2001) 2158 UNTS 3 ('CAAU').

33 See, eg, Article 2 TEU; Article 4(m) CAAU.

34 World Summit Outcome, UNGA Res 60/1 (16 September 2005) UN Doc A/ RES/60/1, paras 119, 134.

35 Most recently: UNGA Res 74/191 (18 December 2019) UN Doc A/RES/74/191.

36 See Machiko Kanetake, 'The Interfaces Between the National and International Rule of Law: A Framework Paper' in Machiko Kanetake and André Nollkaemper (eds), The Rule of Law at the National and International Levels: Contestations and Deference 
twentieth and twenty-first centuries, especially since the end of the Second World War and, with renewed impetus, since the end of the Cold War, international law has developed significantly. ${ }^{37}$ Developments concerning the regulated subject matters, the available actors and the processes of law making, law application and law enforcement can be observed. ${ }^{38}$ Accordingly, international law now regulates an increased number of subject matters, including areas that also concern relations within states, such as human rights, the environment, health, crime, the sea, migration, armed conflict, investment, intellectual property and trade..$^{39}$ It now embraces a variety of actors other than states, most notably international organizations and individuals. ${ }^{40}$ Moreover, international law is now made, applied and enforced through multiple and increasingly sophisticated and institutionalized processes. ${ }^{41}$ As a result, international law and institutions now progressively seek to regulate and control states by requiring, assessing or reviewing the adoption or non-adoption of a certain conduct in relation to other states (approximating a system of public

(Hart Publishing 2016) 15; Kanetake, 'The Case of UN Targeted Sanctions' (ch 1 n 19) 272; Lautenbach (ch 1 n 18) 2-3.

37 Joseph Weiler, 'The Geology of International Law-Governance, Democracy and Legitimacy' (2004) 64 Zeitschrift für ausländisches öffentliches Recht und Völkerrecht 547, 551, 561, speaking of international law's layering, and passim; Mario Prost, The Concept of Unity in Public International Law (Hart Publishing 2012) 4-8. See also Jost Delbrück, 'Prospects for a "World (Internal) Law?": Legal Developments in a Changing International System' (2002) 9 Indiana Journal of Global Legal Studies 401. See, classically, Wolfgang Friedmann, The Changing Structure of International Law (Stevens \& Sons 1964) ch 6.

38 Samantha Besson, Droit international public: précis de droit et résumés de jurisprudence (Stämpfli 2019) paras 55-72; Delbrück (ch 1 n 37) 410-429.

39 Prost (ch 1 n 37) 4; Besson, Droit international public (ch 1 n 38) paras 62-72. See, eg, Statute of the International Criminal Court (adopted 17 July 1998, entered into force 1 July 2002) 2183 UNTS 3 ('ICC Statute'); United Nations Framework Convention on Climate Change (adopted 9 May 1992, entered into force 21 March 1994) 1771 UNTS 107 ('UNFCCC'); Marrakesh Agreement Establishing the World Trade Organization (adopted 15 April 1994, entered into force 1 January 1995) 1867/1868/1869 UNTS 3 ('WTO Agreement'); International Covenant on Economic, Social and Cultural Rights (adopted 16 December 1966, entered into force 3 January 1976) 993 UNTS 3 ('ICESCR'); Geneva Convention for the Amelioration of the Condition of the Wounded and Sick in Armed Forces in the Field (adopted 12 August 1949, entered into force 21 October 1950) 75 UNTS 31 ('Geneva Convention I').

40 Prost (ch 1 n 37) 4-6; Martin Dixon, Textbook on International Law (OUP 2013) $115,117-131$.

${ }_{41}$ Besson, 'The Authority of International Law' (ch 1 n 25) 349; Samantha Besson, 'Theorizing the Sources of International Law' in Samantha Besson and John Tasioulas (eds), The Philosophy of International Law (OUP 2010) 164-165; Mehrdad Payandeh, 'The Concept of International Law in the Jurisprudence of H.L.A. Hart' (2010) 21 European Journal of International Law 967, 982-988; Delbrück (ch 1 n 37) 414-427. 
order between them) or within their jurisdiction, thereby rendering the ROL necessary internationally. ${ }^{42}$ This becomes particularly apparent for areas in which international law sets standards associated with the ROL for domestic legal orders. ${ }^{43}$ Conversely, whereas developments in international law have strengthened the DROL - a case in point being international human rights law-they have also put pressure on it. ${ }^{44}$

The Tadic case $^{45}$ illustrates the need for the ROL internationally. In this case, the defendant challenged the establishment of the International Criminal Tribunal for the Former Yugoslavia ('ICTY'), contending that it had not been 'established by law' within the meaning of, inter alia, Article 14(1) ICCPR, ${ }^{46}$ a fair trial safeguard often associated with the DROL. ${ }^{47}$ The ICTY held that, although this principle only applied in the context of domestic legal orders, 'an international criminal court could [not] be set up at the mere whim of a group of governments. Such a court ought to be rooted in the rule of law', which meant 'it must be established in accordance with the proper international standards; it must provide all the guarantees of fairness, justice and even-handedness, in full conformity with internationally recognized human rights instruments' ${ }^{48}$ To that extent, the ICTY stated, it was 'established by law' ${ }^{49}$ In Tadic, the ICTY tried to interpret a standard prescribed by international law for the domestic level and often associated with the DROL in such a way as to ensure substantial conformity to the underlying values at the international level. ${ }^{50}$

42 Dixon (ch 1 n 40) 3; James Crawford, 'International Law and the Rule of Law' (2003) 24 Adelaide Law Review 3, 10.

43 Crawford, Chance, Order, Change (ch 1 n 13) paras 453, 460.

44 Lautenbach (ch 1 n 18) 2-3.

45 Tadic Case (Decision on the Defence Motion for Interlocutory Appeal on Jurisdiction) ICTY-94-1 (2 October 1995).

46 International Covenant on Civil and Political Rights (adopted 16 December 1966, entered into force 23 March 1976) 999 UNTS 171 ('ICCPR').

47 Tadić, para 41

48 ibid, paras 42,45

49 ibid, para 47.

50 See Crawford, Chance, Order, Change (ch $1 \mathrm{n} \mathrm{13)}$ para 457; Crawford, 'International Law and the Rule of Law' (ch 1 n 42) 9. See also James Crawford and Joe McIntyre, "The Independence and Impartiality of the "International Judiciary" in Shimon Shetreet and Christopher Forsyth (eds), The Culture of Judicial Independence: Conceptual Foundations and Practical Challenges (Martinus Nijhoff Publishers 2012) 203-206. 


\section{THE FOCUS AND THE APPROACH OF THE BOOK}

The book focuses on three fundamental issues: the scope, subjects and requirements of the IROL. First, the scope of the IROL concerns the question of whether, and if so how, the IROL and DROL relate. Generally, the ROL directly pertains to the system and method of government (ie, usually state actions), in issues that are directly relevant to the $\mathrm{ROL}^{51}$ (ie, in connection with the operation of the legal order ${ }^{52}$ ). Domestically, the identity of the legal order is commonly bound up with the identity of the state of which it constitutes the law. ${ }^{53}$ Internationally, where no world state exists, the identity of the international legal order has been contested. In many ways, as James Crawford notes, international law functions in relation to domestic law. This becomes particularly apparent in areas, such as human rights law, where international law regulates intra-state relations. ${ }^{54}$ Thus, the question of the scope of the IROL arises. Whereas different scholars have analysed the IROL independently of the DROL,${ }^{55}$ in view of the interrelations between international and domestic law, particularly where international law regulates areas of intra-state relations, thereby applying (directly or indirectly) to individuals, ${ }^{56}$ such an approach is questionable. ${ }^{57}$ Using insights from both Hans Kelsen and HLA Hart on the identity of legal orders, ${ }^{58}$ the book argues that international and domestic law, although constituting distinct legal orders, are linked and interdependent in various ways. On this basis, it is claimed that, by implication, it is most plausible to conceive of the IROL and DROL as equally interrelated and that, as a result, they need to be approached jointly.

Second, the subjects of the IROL concern the questions of who should exercise its authority within a framework of international law, over whom

\footnotetext{
51 Raz, The Authority of Law (ch 1 n 4) 218.

$52 \quad$ See Lamond (ch 1 n 2) 502.

53 Joseph Raz, 'The Identity of Legal Systems' (1971) 59 California Law Review 795,812 .

${ }^{54}$ Crawford, Chance, Order, Change (ch 1 n 13) para 265.

55 See, eg, Beaulac (ch 1 n 13); Watts (ch 1 n 8).

56 Besson, 'The Authority of International Law' (ch 1 n 25) 349-350 on the concept of legitimate authority.

57 See, eg, Kanetake, 'A Framework Paper' (ch 1 n 36); André Nollkaemper, 'The Bifurcation of International Law: Two Futures for the International Rule of Law' in Sam Muller and others (eds), The Law of the Future and the Future of Law (Torkel Opsahl Academic EPublisher 2011).

58 See Hans Kelsen, Pure Theory of Law (Lawbook Exchange 2008 [1967]) 328-347; HLA Hart, Essays in Jurisprudence and Philosophy (Clarendon Press 1983) 309-342.
} 
and for whose sake. In general, the ROL demands that the government should exercise its authority within a legal framework and that people should obey the law, and it is valued because conformity to it protects individual values, like autonomy. ${ }^{59}$ At the domestic level, the subjects of the ROL, ie, those in and under political authority within a legal order, are usually the state and its instrumentalities, ${ }^{60}$ and individuals. ${ }^{61}$ At the international level, where primarily states, but progressively also international organizations, are involved in the making, application and enforcement of international law, and where primarily states, but also international organizations and - to a limited degree but increasingly so - individuals, are called to obey international law, the question of the subjects of the IROL arises. ${ }^{62}$ While some scholars have put emphasis on states as subjects of the IROL, ${ }^{63}$ others have rightly factored in other types of persons and entities, such as international organizations and individuals. ${ }^{64}$ Only a limited number of scholars have, in addition to that, explicitly distinguished between those in and under political authority within the international legal order and analysed the manner in which states and international organizations connect to each other and to individuals. ${ }^{65}$ However, this distinction and connection are important because the burdens imposed by the ROL are different in each case and the possibility and desirability of the IROL depend on the involvement of human beings. ${ }^{66}$ The book argues that, within the international legal order, primarily states, but also international organizations and to a limited extent individuals, exercise political authority and should thus do so within a framework of international law, primarily over states, but also over international organizations and, increasingly, over individuals too, who should thus obey international law. The book also contends that understanding states

Waldron, 'The Rule of Law' (ch 1 n 5).

${ }^{60}$ Lamond (ch 1 n 2) 500.

${ }^{61}$ See Besson, 'The Authority of International Law' (ch 1 n 25) 358 on the concept of legitimate authority.

${ }^{62}$ On this issue, see Waldron, 'Are Sovereigns Entitled to the Benefit of the International Rule of Law?' (ch 1 n 13).

${ }_{63}$ See, eg, Beaulac (ch 1 n 13); Watts (ch 1 n 8).

${ }^{64}$ See, eg, Chesterman, 'An International Rule of Law?' (ch 1 n 21) 355-360; Owada (ch 1 n 21); Nollkaemper, 'The Bifurcation of International Law' (ch 1 n 57); Robinson (ch 1 n 18).

${ }_{65}$ See Waldron, 'Are Sovereigns Entitled to the Benefit of the International Rule of Law?' (ch 1 n 13); Besson, 'Sovereignty, International Law and Democracy' (ch $1 \mathrm{n}$ 25). See also, eg, Kanetake, 'A Framework Paper' (ch 1 n 36) 15-18.

${ }_{66}$ On the whole issue, Besson, 'The Authority of International Law' (ch $1 \mathrm{n}$ 25) 350, 359-360 regarding the concept of legitimate authority; Liam Murphy, 'International Responsibility' in Samantha Besson and John Tasioulas (eds), The Philosophy of International Law (OUP 2010) 301. 
or international organizations qua subjects of the IROL requires considering how they connect to individuals.

Third, the requirements of the IROL concern the questions of what the ROL demands at the international level and how, and to what degree, the international legal order can and does conform to and develop the principle. Generally, the availability, importance and detailed design of various requirements of the ROL depend on the social and cultural conditions prevailing within individual legal orders. ${ }^{67}$ Domestically, legal orders generally exhibit some specific features beside the ones they share with one another. Internationally, the law also possesses its own particularities besides the features it shares with domestic law. At first blush, international law appears to differ more from domestic law than domestic legal orders from one another. Thus, the question of the requirements of the IROL arises. Scholars have generally articulated the requirements of the IROL on the basis of existing ROL theories. ${ }^{68}$ In the book, it is claimed that such an approach is justified in the face of the legal nature of international law and international law's recent developments. However, drawing on arguments made by scholars in the context of general theories on law, the book also argues that, to the extent that existing ROL theories consider the DROL as the paradigm case of legal governance, such an approach should not remain unchallenged. There is no compelling reason why theories of the ROL in general should be more closely attached to domestic than international law. ${ }^{69}$ Moreover, in view of the increased interrelations between international and domestic law based on the developments of international law, domestic law itself has arguably changed, requiring a review of ROL theories built on the basis of domestic law anyway. ${ }^{70}$ The analysis of the requirements of the IROL should thus provoke a rethink of the requirements of existing ROL theories. Conversely, similar considerations hold true for the analysis of the requirements of the DROL, which should take into account the international level.

The book analyses the possibility and degree of development of three ROL requirements at the international level: (1) legal generality; (2) legal publicity; and (3) legal non-conflictingness and non-contradictoriness. These requirements remain undertheorized in the IROL scholarship. In addition, theorizing

\footnotetext{
67 See Raz, The Authority of Law (ch 1 n 4) 214; Lamond (ch 1 n 2) 502.

68 See, eg, Rijpkema (ch 1 n 13); Waldron, 'Are Sovereigns Entitled to the Benefit of the International Rule of Law?' (ch 1 n 13); Beaulac (ch 1 n 13); Crawford, Chance, Order, Change (ch $1 \mathrm{n}$ 13) chs XI-XV; Chesterman, 'An International Rule of Law?' (ch 1 n 21); Pablo Arrocha Olabuenaga, 'Consideraciones sobre el Estado de derecho en el plano internacional' (2010) 10 Anuario Mexicano de Derecho Internacional 173.

69 Payandeh (ch $1 \mathrm{n} 41) 980$.

70 Besson and Tasioulas (ch $1 \mathrm{n}$ 27) 8-9, 13; William Twining, Globalisation and Legal Theory (Butterworths 2000) 51.
} 
them enables us to take a stand on some of the controversial questions of international law from a ROL perspective.

The approach of this book is theoretical and integrated. First, the book elucidates the IROL from a legal theoretical perspective. International law is used to illustrate the theoretical arguments. The book does not provide a doctrinal analysis of the general and special international law on the IROL. Neither does it engage in such an analysis of the relevant case law of universal or regional courts. The book draws on the tradition of analytical jurisprudence, starting from the premise that this tradition has a contribution to make to the theorizing of the IROL. Unlike various approaches inspired by post-modernism, ${ }^{71}$ which are sceptical about reason, the tradition of philosophical thought adopted in this book holds that an intellectually respectable form of conceptual and normative inquiry is possible. ${ }^{72}$ Of course, the tradition of analytical jurisprudence brings a certain legal background to the ROL concept used in this book. However, this background does not necessarily inhere in the inquiry itself, which may remain universal, to the extent that its reasoning and conclusions are valid across legal cultures (even if the concept of the ROL itself is parochial). ${ }^{73}$ Second, the approach of the book is integrated insofar as it encompasses both the international and domestic legal orders. This is reflected by the new approach to the IROL fleshed out by this book, which implies understanding the IROL together with, and closely related to, the DROL.

Some further delimitations are appropriate. First, the ROL prominently features in the literature on global constitutionalism and global administrative law ('GAL'). The ROL is one of the 'constitutional features'-the others being: a balance or separation of powers, constituent power and rights - that global constitutionalism requires a global political and legal order to possess in order to be capable of both enabling and constraining political decision making and, thus, to qualify as constitutional. ${ }^{74}$ Elements often associated with

${ }^{71}$ See, eg, Martti Koskenniemi, From Apology to Utopia: The Structure of International Legal Argument (CUP 2005); David Kennedy, 'Challenging Expert Rule: The Politics of Global Governance’ (2004) 27 Sydney Law Review 1.

72 Besson and Tasioulas (ch 1 n 27) 3-4.

73 On theories of law, Joseph Raz, 'Can There Be a Theory of Law?' in Martin Golding and William Edmundson (eds), The Blackwell Guide to the Philosophy of Law and Legal Theory (Blackwell 2006) 332 and passim; Samantha Besson, "Moral Philosophy and International Law' in Anne Orford and Florian Hoffmann (eds), The Oxford Handbook of the Theory of International Law (OUP 2016) 403. See, further, Joseph Raz, Between Authority and Interpretation: On the Theory of Law and Practical Reason (OUP 2009) 91-106. A more detailed discussion on the question of the universality of the ROL, in particular regarding the law of the ROL, can be found in ch 3, s 4 .

${ }^{74}$ See Anthony Lang and Antje Wiener, 'A Constitutionalising Global Order: An Introduction' in Anthony Lang and Antje Wiener (eds), Handbook on Global Constitutionalism (Edward Elgar Publishing 2017) 2-3. 
the ROL, such as transparency or effective review, form part of GAL, ie, the mechanisms, principles and practices promoting the accountability of global administrative bodies. ${ }^{75}$ Unlike both the global constitutionalist and GAL projects, which ultimately deal with the legitimacy or justification of the exercise of power beyond the state, this book's undertaking is primarily concerned with the IROL qua international legality or inherent virtue of international law. In addition, in contrast to at least the GAL project, this book endorses a non-expansive view of law, which only includes norms stemming from the formal sources of international law. ${ }^{76}$

Second, the ROL is contained in the literature on law and development, law and globalization, and comparative law. This book differs from the law and development literature. It concerns the ROL as a principle directed at the international legal order and not the ROL as a principle directed at domestic legal orders and promoted through domestic or international institutions. As for the literature on law and globalization and comparative law, some insights have been incorporated in this book. ${ }^{77}$

\section{THE STRUCTURE OF THE BOOK}

The book comprises 11 chapters including introduction and conclusion. Chapter 2 is devoted to clarifying the ROL concept. A clear understanding of the ROL concept is needed to study it within the international legal order. The chapter specifically considers the nature of the ROL concept, the ROL being a principle both for government and law. ${ }^{78}$ Briefly contemplating the controversy surrounding the meaning of the ROL, it engages in a critical review of the distinction, popular in conventional ROL scholarship, between formal and substantive theories of the ROL. Finally, Chapter 2 develops in detail the conception of the ROL employed in the book out of two influential conceptions from contemporary legal theory.

Chapter 3 is devoted to the value of the ROL and critically discusses some questions that are raised in this context. It first appraises the claim advanced by many scholars that observing the ROL enhances the value of individual autonomy. The chapter then reflects on the relationship between the ROL, law

75 See Benedict Kingsbury, Nico Krisch and Richard Stewart, 'The Emergence of Global Administrative Law' (2005) 68 Law and Contemporary Problems 15, 17.

76 See Benedict Kingsbury, Megan Donaldson and Rodrigo Vallejo, 'Global Administrative Law and Deliberative Democracy' in Anne Orford and Florian Hoffmann (eds), The Oxford Handbook of the Theory of International Law (OUP 2016) $527-532$.

77 See, eg, chs 3 and 5.

78 Gardner, Law as a Leap of Faith (ch 1 n 6) 214. 
and morality. It evaluates, in particular, the contention made by some scholars that a legal order that conforms to the ROL is likely to be morally valuable as a whole. Chapter 3 also engages with the question of the universality of the ROL. It specifically addresses the challenge of parochialism, which can be raised against positive international law norms guaranteeing the IROL and DROL based on moral pluralism, and discusses possible mitigations. In this context, the legal ROL doctrines of three domestic legal orders are examined.

Chapter 4 is devoted to a general description of the emergence of the ROL in international law and practice, serving as a backdrop to the normative argument about the IROL advanced in the remainder of the book. The chapter is divided into two sections. The first section deals with aspects of international law and practice of the ROL as an international principle directed at the legal orders of states. It specifically addresses the ROL as advocated, guaranteed and practised in the areas of human rights, peace and security, development and regional integration, focusing on international institutions such as the Council of Europe ('CoE'), the OSCE, the EU, the Organization of American States ('OAS'), the AU, the Association of Southeast Asian Nations ('ASEAN'), the World Bank and the UN. In its second section, the chapter deals with aspects of international law and practice of the ROL as an international principle directed at the international legal order. Emphasis is placed on regional organizations such as the EU, the AU, the ASEAN, as well as the UN on the universal plane.

Chapter 5 is devoted to examining two 'preconditional' questions for the IROL's possibility. It first addresses the question of the legal nature of international law by discussing possible responses to the challenge advanced by some scholars that international law does not qualify as law or a legal system since necessary conditions of law or a legal system are missing. The chapter then reflects on the question of the 'suitability' or 'applicability' of the ROL in the international law context. Doubts as to whether international law can conform to and develop the ROL have been voiced, based on the differences between the international and domestic legal orders. Chapter 5 specifically considers whether the particularities of the international legal order require a reconceptualization of the ROL at the international level.

Chapter 6 is devoted to the scope of the IROL. It starts with an examination of the interrelations between international and domestic law in order to draw and discuss possible implications for the interrelations between the ROL at the international and domestic levels. Chapter 6 also addresses the issue of conflicts between the IROL and DROL. It further deals with the claim advanced by some scholars that the realization of the IROL and DROL as a matter of international law would lead to a world law and a world state and, seemingly, a world ROL.

Chapter 7 is devoted to the subjects of the IROL. It first examines the identity of those who are in political authority within the international legal order. 
More specifically, it considers the issue of the absence of a world government and specifies the persons and entities that officially make, apply and enforce international law. The chapter also reflects on the way in which these persons and entities differ from and relate to one another, their ROL burdens, and conflicts of ROL requirements. Second, Chapter 7 addresses the identity of those who are under political authority within the international legal order. Specifically, it deals with the issue of the absence of a world people and specifies the persons and entities that are officially called to obey international law. The chapter also examines the way in which these persons and entities differ from and relate to one another, their ROL burdens and benefits, and conflicts of ROL requirements.

Chapters 8 to 10 are devoted to analysing the possibility and degree of realization of the three ROL requirements at the international level: legal generality (Chapter 8), legal publicity (Chapter 9), and legal non-conflictingness and non-contradictoriness (Chapter 10). The chapters start by conceiving international legal generality, publicity, and non-conflictingness and non-contradictoriness. More specifically, they restate what these notions mean in the ROL context, reformulate them in international law terms and distinguish them from similar notions in international law. The chapters then proceed to an examination of the question of whether, and if so how and to what degree, contemporary international law can conform to and develop legal generality, publicity, and non-conflictingness and non-contradictoriness. Based on the findings, Chapters 8 to 10 then rethink legal generality, publicity, and non-conflictingness and non-contradictoriness.

The concluding Chapter 11 is divided into two sections. The first deals with the implications of the interrelations between the IROL and DROL for the DROL and provides an integrated account of the IROL. In its second section, Chapter 11 summarizes the main arguments of the book and evaluates them in a broader context, offering general conclusions and prospects. 